\title{
Meta
}

Journal des traducteurs

Translators' Journal

\section{Some Reflections on "Equivalence”/“Äquivalenz" as a Term and a Concept in the Theory of Translation}

\section{Jennifer Kewley Draskau}

Volume 36, numéro 1, mars 1991

La terminologie dans le monde : orientations et recherches

URI : https://id.erudit.org/iderudit/002586ar

DOI : https://doi.org/10.7202/002586ar

Aller au sommaire du numéro

Éditeur(s)

Les Presses de l'Université de Montréal

ISSN

0026-0452 (imprimé)

Découvrir la revue

Citer cet article

Kewley Draskau, J. (1991). Some Reflections on "Equivalence”/“Äquivalenz” as a Term and a Concept in the Theory of Translation. Meta, 36(1), 269-274. https://doi.org/10.7202/002586ar
Résumé de l'article

La question des langues de spécialité est-elle si importante? Est-il possible de faire référence à un seul concept " équivalent/équivalence » en anglais ou en allemand? Dans l'affirmative, ce concept est-il le seul à être aussi imprécis et obscur à l'intérieur du champ de la théorie de la traduction? Un examen du concept EQ/AQ, tel que présenté dans les ouvrages, est ensuite proposé. 


\title{
SOME REFLECTIONS ON "EQUIVALENCE"/“ÄQUIVALENZ" AS A TERM AND A CONCEPT IN THE THEORY OF TRANSLATION
}

JeNNIFER KEWLEY DRASKaU

University of Copenhagen, Copenhagen, Denmark

\begin{abstract}
RÉSUMÉ
La question des langues de spécialité est-elle si importante? Est-il possible de faire référence à un seul concept «équivalent/équivalence» en anglais ou en allemand? Dans l'affirmative, ce concept est-il le seul à être aussi imprécis et obscur à l'intérieur du champ de la théorie de la traduction? Un examen du concept $\mathrm{EQ} / \mathrm{AQ}$, tel que présenté dans les ouvrages, est ensuite proposé.
\end{abstract}

\section{THE OBLIGATORY LAMENTATION}

The concept(s) of equivalence and equivalent(s), German: Aquivalenz/$\ddot{A}(\ddot{a})$ quivalent, hereinafter $\mathrm{EQ} / \mathrm{AQ}$, may be regarded as a pivotal element of translation theory (Arntz/Pitch 1989: 158; Pedersen 1987: 94; Wilss 1988: 24, quoting Koller 1979; etc.). In Britain, we say that everyone talks about the weather but no one does anything about it. Similarly, in recent years every new work on translation theory has included an obligato lamentation on the elusiveness of EQ/AQ, almost as though this, like the weather, were some ever-present and inevitable Act of God visited upon translation theory by a malignant deity (for examples, Wilss 1988: 49: "die notorische Diskussion zum uw Evergreen der Übersetzungsäquivalenz" (uw = Übersetzungswissenschaft); Turk 1988: 89; Neubert 1988: 77, etc.). Some authorities disavow it entirely. Snell-Hornby (1986: 13ff, "Illusion der Äquivalenz": and 1988: 433ff) notes that not only is the concept fallacious, but that the English and the German terms are "used with subtle differences in meaning." In keeping with her position on the question, she eschews the term equivalent, for which she quotes the explanation offered in the Oxford English Dictionary, "approximately the same thing." It is not stated which Oxford Dictionary was consulted, but presumably it was a general dictionary.

\section{WHY THE CHORUS OF LAMENTATIONS?}

a) - Is the matter of LSP - the language in which the theories of a special field are couched - really so crucial?

b) - Is it possible to refer to one, unified and unambiguous, concept of EQ/AQ in either English or German? If so, is this concept unique in its vagueness and "murkiness" ("dunkel": Schwarz 1983: 171) within the special field of translation theory?

Ad. a) It should first be established that when reference is being made to the linguistic expression of the theoretical concepts of a special field, "general-language" definitions cease to apply. The only relevant definition is that which may be established within a given theoretical framework. This applies in particular to those terms (in the sense of the theory of terminology) which are either misleadingly familiar to "the language used for general purposes" (LGP) or from the theoretical conceptual apparatus of other 
disciplines. "EQ/AQ" may be encountered not only in LGP, but in the LSPs of mathematics, logic, cognition theory and the social sciences (Luhmann 1970); in relation to the latter field, Budin's terminological study (1988) is of considerable interest.

The importance of the language of the specific field (of which its terminology constitutes a seminal component) is that the theories of the so-called "soft sciences" are comprised of conceptual relations which can only be expressed in natural language. The fundamental bricks-and-mortar of any theory are its concepts and the relations obtaining among them. These concepts are realized at the expression level by means of signs which have the status of terms, syntactically linked and embedded in the LSP co-textual environment. The classification of concepts is undertaken on the basis of characteristics. Characteristics are essential for the identification of a concept and its differentiation from other concepts of a specific field (ISO 704 1987: 2, Arntz/Picht 1989: 54 cit.). A concept, often defined as a "unit of thought" (Wüster "Denkeinheit": 1985: 7), consists of the sum of its characteristics (intension). But these characteristics are also concepts, with characteristics of their own. Consequently, the nature of any concept is a relational complex. In the soft sciences, as Budin (1988) has shown, concepts frequently remain theoretical and incapable of convincing empirical demonstration, murky and obscure rather than decisively defined. This applies equally to their characteristics, so far as any attempt has been made to identify them. The lack of clarity in the theoretical apparatus of translation theory jeopardizes the theory itself; it prohibits, moreover, the mutually beneficial, indeed mandatory, interaction of theory and practice, by rendering the accumulation and exploitation of empirical data problematic, and relegating the practice of translation once more to the "intuitions" (Wilss 1988: 140), "discretion" (Kelly 1979: 217) "instincts" or "conscience" of the individual translator, who will seek support from the theoretical framework in vain.

Ad. b) No general agreement prevails on definitions of translational EQ/AQ. Moreover, one may suspect that $\mathrm{EQ} / \mathrm{AQ}$ is not an isolated case; lack of definition and stringent applications may also lurk elsewhere in the LSP of translation theory.

I now propose to consider the concept(s) of $\mathrm{EQ} / \mathrm{AQ}$ in the more recent work of some leading translation theorists. It will be understood that, in the space available, this cannot claim to be a thorough terminological analysis.

Firstly, concept(s) of $\mathrm{EQ} / \mathrm{AQ}$ would be evaluative in nature, rather than pretending to descriptive accuracy, since they are based on value judgements and prescriptive statements; notwithstanding, on the cognitive level such concept(s) would constitute "units of thought" expressed, by a term for communicative purposes within the special field. Budin (1988: 69) would regard this situation as interaktiv-dynamisch, on the grounds that concepts which have once achieved formulation and a certain currency proceed thereafter to exert an influence on the emergence of all new concepts, with both theoretical and practical consequences. (A somewhat comparable cumulative effect has been noted within the field of translation theory by Wilss (1988: 126), quoting the "increasing strength hypothesis" of Wickelgren 1979). One of the difficulties about examining EQ/AQ is not only that the concepts are left undefined or are defined only partially, but that the characteristics may occur randomly scattered throughout the text, or remain implicit rather than explicit. Characteristics are thus assumed cumulatively, and at times contradictorily, as the theoretical argumentation proceeds, so that the intension of the concepts emerges and may undergo modification under the influence of the development of the theory, rather than achieving initial definition which would enable it to be maintained and to function as a conerstone in the theoretical edifice. Hence, the conceptual system, which should constitute the basis for the development of the argumentation, in fact is subjugated and therefore modified by it. It should be noted that 
the terminological ideal of Eineindeutigkeit (Arntz/Picht 1989: 117), the monosemous one-to-one relationship between terms and concepts, i.e., a communicative situation untainted by synonymy, homonymy or polysemy, is, naturally, almost certainly even more Utopian in a soft science than elsewhere (and despite the folklore, Eineindeutigkeit as an ideal is largely illusory, even in the fields of science and technology).

Apparent synonyms and quasi-synonyms for EQ/AQ abound; thus Pedersen, following Ogden and Richards (1923:90) "strict similarity of reference" (1987: 94); Nida "matching" of the message (1964: 159) and "functional similarity" (1986: 63); Neubert Übereinstimmung, Stimmigkeit (1988: 78); Steiner "conservation of energies of meaning" (1975: 300ff); Turk Gleichheit, Gleichartigkeit and Gleichgewicht (1988: 89ff) (the last of these evoking connotations of the notion of restitution of equilibrium in the hermeneutics of Steiner (1975: 395) and Kelly (1979: 61). Kelly also speaks of "parity" (1979: 182); Nida and de Waard, "correspondence" (1986: 36).

Differences in intension can only be ascertained by a comparison of the configuration of the characteristics in a definition.

Where no definition is offered, the reader is obliged to draw his own conclusions as to the intension, on the basis of the applications; there is no guarantee that this interpretation will concur with the author's intent.

One of the few theorists to redefine his terminology diachronically is Nida; it is no coincidence that, despite the problematic nature of some of Nida's concepts, notably that of equivalent effect or comparable receptor experience (attacked by Meschonnic 1973: 349f); echoed by the Beaugrande (1980: 24: "EQ of reader experience"), it is possible, as Wilss does (1988: 135), to speak of Adäquatheitsnormen der Z(iel)s(prache) im Sinne des NIDAschen Prinzips des 'closest natural equivalent'".

Nida initially (1964) operates with the concepts of formal and dynamic EQ. "Formal EQ focusses attention on the message itself, in both form and content"... the matching of elements; ... standards of accuracy and correctness are imposed upon it. Dynamic EQ, in contrast, is based upon "the principle of equivalent effect... the relationship between receptor and message should be substantially the same as that which existed between the original receptors and the message." (1964: 159). Dynamic EQ is retermed (Nida and Taber: 1969) "functional EQ," and Nida and de Waard maintain (1986: 36) that the essential characteristics remain the same, i.e. functional EQ is bound up in, and unisolatable from, the communication situation; it focusses on the representation of content rather than form, except where, as in "aesthetic function", the form is an integral part of the meaning; the role of the receptor is "integral", his perception of the TL message as "natural" remains a basic criterion, as in Nida (1964: 166). The adoption of the new term "functional" is motivated by the connotations of the term "dynamic", often misunderstood as implying "merely impact and appeal". Formal EQ later renamed, without redefinition, "formal correspondence", should not be identified with "literality of translation strategy", since "an expression in any language consists of a set of forms which serve to signal meaning on various levels: lexical, grammatical and rhetorical. The translator must seek to employ a functionally equivalent set of forms which will match the meaning of the original" (1986: 36). Nonetheless, in Nida's classification of the five translation types (1986: 40), the central type, "the closest natural equivalent", stands in contrast to the "literal", which "adheres to the form of the original as much as possible."

(The term "functional" in Nida's theory clearly stands in an antonymous relation to the use of "merely functional translation" in Newmark (1988: 21) where, it is claimed, "such a translation may be $100 \%$ successful, even though the niceties of equivalent description and register may be missing.") 
What is the relationship between form and function? Kelly (1979: 24) appears at first to suggest a binary opposition, offering Nida's definition for dynamic $\mathrm{EQ}$, and for formal EQ, "correspondence between linguistic units, independent of any idea of content", illustrated by Beekman's highly programmatic graphic representation (1965: 88). Later Kelly states that both EQ types may exist in the same item, but does not provide examples (1979: 25). Or is the relationship between form and function one of subordination, as Nida suggests, introducing Hofstader's notion of the isomorphic series (Hofstadter 1980; cit. Nida 1986: 63f). To be functionally equivalent, the isomorphic series in translation must be information-preserving rather than information-altering, through the subordination of differences of form to functional similarity.

Turk (1988: 90) finds the notion of $\mathrm{AQ}$ of form untenable in translation, since $\mathrm{AQ}$ of elements from two language systems may not be ascertained through substitution, but only in relation to a "tertium" - a concept which lies outside both systems. For AQ to occur, it is essential that Gleichheit in one respect or on one level be linked with Ungleichheit on another. The existence of strict AQ may be posited between the Latin sign arbor and the German sign Baum solely because they are ungleich at the expression level, while being auf der Inhaltund Wirkungsebene gleich."

Turk makes a serious attempt to distinguish AQ from Adäquatheit and Korrespondenz, often linked together or less loosely by other translation theorists (see for example Wilss 1988: 135, op. cit.); Neubert (1988: 79, 84), et al.). In Turk's analysis, AQ lasst an Austauschbarkeit denken (1988: 87) Adequatheit "eine fortschreitende Annahrung", and Korrespondenz "eine Homologie von Ubersetzung und Original". It is because of its relationship with a tertiary, its Dreistelligkeit, that AQ has become rahmengebend for translation theory.

This suggests a return to the Augustinian principle of the identity of significatio, listed by Kelly (1979: 131) as the most obvious of the three possible ways of assessing $\mathrm{EQ}$. The third possible way is stated as "EQ on the affective level". Kelly employs the term EQ for at least two other different concepts, besides the circular statement quoted above; as translatorial goal and/or strategy (the translator's... selection of EQ" (in the section headed "Lexical Techniques", 1979: 131); and as a datum or absolute: "Traditional attacks on unrelieved formal EQ" (1979: 139). He collapses Nida's distinction between formality and literality; often, his definitions provoke more questions than they answer; for example: (139) "The hallmarks of formal EQ are refusal to change the direction of the linguistic sign...". EQ is assumed to include "the effects that each element in the triangle of signifiant, signifie and speaker has on the rest of the triangle." (131). "Formal EQ so emphasizes the link between signifiant and signifié that one tends to forget its conventionality through institutionalizing the link. Dynamic EQ plays up the conventional and arbitrary nature of the sign by concentrating on the response, on the presence of the person." (131)

Dynamic EQ "may add meanings", "can create a whole new picture", "is concerned solely with communicative function, normally abstracting from formal identity". (146) "The imitation of sound values... is one of the elements of dynamic EQ." (155). These statements invite a number of queries. How is it possible to posit "EQ of meaning" if "new meanings" are added? How may "formal identity" or "unrelieved formal EQ" be maintained in the course of a process of transposition from one language system to another? Since when has phonology not constituted a formal as well as substantial element in the grammar of a language system? These characteristics are somewhat problematical in the configuration of the intension. Similarly, such statements as "dynamic EQ is resorted to where the rhythm and flow of the source text is an essential 
part of the message" (192) may hardly be said to shed much light on the relevance of formal expression elements for aesthetic function.

De Beaugrande's concern for the preservation of aesthetic values (1980: 23) reflects Nida's preoccupations: "in the translation of literature, EQ of reader experience is a higher goal than EQ of the means used to elicit those experiences." EQ here is both a goal and a means to achieving a goal, two applications on different levels of analysis, and hence two different concepts. Later, (26), equivalents are capable of being "selected": it is unclear whether "equivalent" here denotes a TL approximation or alternative, or a unit of translation tacitly assumed to enter into a relationship of "equivalence" with the SL unit, on the basis of the SL macrotext (see also Neubert 1988: 79; Newmark 1988: 26; Wilss 1988: 140). Here, too, EQ of expression elements (words and phrases) is apparently a possible aim for the "literal" translator, albeit one which de Beaugrande (27) understandably dismisses as "misguided" (in the light of Turk's analysis, EQ of elements on the formal level would be not only undesirable but impossible in translation). And Neubert reminds us: Aquivalente sind... nicht Zeichenfolgen. Sie realisieren sie nur. Sie sind Träger oder Hüllen der Äquivalenz. Äquivalent sind die kommunikativen Werte der Zeichenfolge in ihrem kommunikativen Umfeld." (1988: 86)

Wilss (1988) in many respects typifies the translation theorists ambivalent attitude towards EQ/AQ. Having duly deplored the lack of valid definitions (1988: 24, op cit.), he proceeds as though a definition had been established: for instance (1988: 79), the goal stated for acts of translation is to produce, in consideration of sense, function, and in comparable circumstances, a "möglichst äquivalenten Zieltext." Despite pleas for criteria for assessing AQ (96), AQforderungen are referred to (104) as though the term expressed a readily communicable concept, while (139) "akzeptable Äquivalente" for "stilistisch markierte Textstellen" are identified as solutions which will not destroy the "stilistischen Reiz" of the original through "mehr oder minder weit ausholende lexikalische und syntaktische Ausdrucksverschiebungen."

All in all, despite general deprecation, the controversial concept of "EQ/AQ" continues to flourish; where characteristics are listed, they suffer from the same syndrome. Those who have attempted to distinguish the concept of EQ/AQ from neighbouring concepts, as Turk does, are in a minority. Often, correspondence, adequacy and the like are either used quasi-synonymously or are classified, without further definition, as essential characteristics of $\mathrm{EQ} / \mathrm{AQ}$.

\section{CONCLUSION}

As these limited examples illustrate, from the point of view of the theory of terminology a distressing disorderliness prevails in translation theories. First, the lack of definitions and consistency and the superabundance of homonyms and polysemes complicate communication within the field to an invalidating degree, virtually precluding the profitable comparison and evaluation of the various theories.

Second, the insufficient identification, by means of adequate definition, of the fundamental concepts of a given theory results in an opacity which prevents any viable assess of the consistent stringency of that theory; in the best cases, where a coherent theory is in fact present, it remains unrevealed, entombed within the mind of its creator: the receptor is debarred from all possibility of assessing it. In the worst case, the deficient consistency and coherence of the theory remain undisclosed, even to the theorist himself, through the lack of stringency of the conceptual apparatus. 


\section{BIBLIOGRAHY}

ARNTZ, Reiner and Heribert PICHT (1989): Einführung in die Terminologiearbeit, Hildesheim.

DE BEAUGRANDE, Robert (1980): "Toward a Semiotic Theory of Literary Translating", Wills, Wolfram, Semiotik und Ubersetzen, Tübingen.

BEEKMAN, J. (1965): Notes on Translation with Drills, Summer Institute of Linguistics, California.

BUDIN, Gerhard (1988): Möglichkeiten und Grenzen der Terminologieforschung in den Sozialwissenschaften, Vienna.

HOFSTADTER, Douglas R. (1980): Goedel, Escher, Bach. An Eternal Golden Braid, New York.

KANDELAKI, T. L. (1977): Semantika i mitivirovannost terminov, Moscow.

KELLY, L. G. (1979): The True Interpreter, Oxford.

LUHMANN, Niklas (1970): Soziologische Aufklärung: Aufsätze zur Theorie sozialer Systeme, Cologne.

MESCHONNIC, H. (1973): Pour la poétique II, Paris.

NEUBERT, Albrecht (1988): "Textbezogene Äquivalenz", Arntz, Reiner (ed.), Textlinguistik Fachsprache, Hildesheim.

NEWMARK, Peter (1988): Translation and Mistranslation, Reiner Arntz (ed.), Textlinguistik und Fachsprache, Hildesheim.

NIDA, E. A. (1964): Toward a Science of Translating, Leiden.

NIDA, E. A. and C. R. TABER (1969): The Theory and Practice of Translation, Leiden.

NIDA, E.A. and Jan DE WAARD (1986): From One Language to Another. Functional Equivalence in Bible Translating, Nashville.

OGDEN, C.K. and I.A. RICHARDS (1923): The Meaning of Meaning, London, (10 edition).

PEDERSEN, Viggo Hjornager (1987): Oversaettelsesteori, Copenhagen, (3ri edition).

SCHWARZ, Richard L. (1983): Der Begriff des Begriffes in der philosophischen Lexikographie, Munich.

SNELL-HORNBY, Mary (1986): "Übersetzen, Sprache, Kultur", Snell-Horby, Mary (ed.), Übersetzungswissenschaft - eine Neuorientierung. Zur Integrierung von Theorie und Praxis, Tübingen.

SNELL-HORNBY, Mary (1988): "The role of text linguistics in a theory of literary translation", Arntz, Reiner (ed.), Textlinguistik und Fachsprache, Hildesheim.

STEINER, George (1975): After Babel: Aspects of Language and Translation, London.

TURK, Horst (1988): “Adäquatheit, Äquivalenz, Korrespondenz. Der kategoriale Rahmen der Übersetzungsanalyse", Arntz, Reiner (ed.), Textlinguistik und Fachsprache. Hildesheim.

WICKELGREN, W. A. (1979): Cognitive Psychology, New Jersey.

WILSS, Wolfram (1988): Kognition und Übersetzen, Tübingen.

WUSTER, E. (1970): Internationale Sprachnormung in der Technik, besonders in der Elektrotechnik, Berlin.

WÜSTER, E. (1985): Einführung in die Allgemeine Terminologielehre und die Terminologische Lexikographie, 2 , unveränd, Aufl, Copenhagen. 